\title{
MAKNA MITOLOGIS LEGENDA JAKA POLENG
}

\author{
WIKA SOVIANA DEVI \\ Pengajar Sekolah Menengah Pertama Teuku Umar Semarang \\ 085742470074 wikasoviana@ymail.com
}

\begin{abstract}
Jaka Poleng legend is a folklore with several versions developed in the northern coastal area of Brebes. Comparing the oral and written versions of Jaka Poleng story resulted in some differences in the transformation of Jaka Poleng into a snake. The public response of the mythological meaning of the Jaka Poleng story is the reaction toward the existence of Jaka Poleng figure. This figure is believed to remain exist in one room in the Pendopo Kabupaten of Brebes. Some believe that Jaka Poleng is the guardian of Brebes people.
\end{abstract}

Key words: Folklore, legend, mythologic meaning, Brebes area, Central Java

\section{Pendahuluan}

Salah satu cerita rakyat yang berkembang di daerah Brebes adalah Legenda Jaka Poleng. Cerita tersebut dikenal di lingkungan pendopo dan di luar pendopo Kabupaten, dan menjadi cerita khas yang berasal dari Brebes. Bukti fisik kelanggengan cerita tersebut pun masih dapat dilihat dengan adanya kamar yang diyakini sebagai kamar Jaka Poleng dan ritual-ritual yang selalu dilakukan untuk merawat kamar tersebut. Pada malam-malam Selasa Kliwon dan Jumat Kliwon, kamar Jaka Poleng dibersihkan dan diberi sesaji lengkap berupa makanan, kemenyan, minuman kopi atau teh yang diletakkan di atas tempat tidur. Untuk hari-hari biasa sesaji hanya berupa minuman teh atau kopi. Kamar tersebut ditata rapi oleh juru kunci yang dipercaya oleh Bupati. Ada anggapan bagi siapa saja yang diberi firasat atau mimpi bertemu dengan sosok Jaka Poleng akan membawa berkah bagi orang tersebut.

Cerita Jaka Poleng memiliki berbagai versi sesuai dengan ciri tradisi lisan yaitu memiliki keragaman versi. Satu versi (Yudiono, 2005) menyatakan bahwa tokoh Jaka Poleng merupakan Pendekar Gunung Padang yang dibunuh oleh Raja 
Bumi Pakuwon, tanpa melakukan kesalahan. Jaka Poleng sebagai seekor naga belang membantu Ciung Wanara. Versi lain, Jaka Poleng adalah seorang pemelihara kuda yang dibawa oleh Kiai Sura (Bupati Brebes). Si pemelihara kuda tersebut pada suatu saat melihat ular belang sedang melepas kulitnya. Kulit tersebut ditelan oleh si pemelihara kuda karena akan direbut oleh Kiai Sura. Setelah menelan kulit ular tersebut ia menjadi berbadan halus dan diabadikan dengan nama Jaka Poleng (Supardi, 1998). Kesamaan dari versi-versi cerita Jaka Poleng adalah pelukisan profil tokoh yang diwujudkan dalam bentuk seekor ular yang berkulit poleng.

\section{Perbandingan}

\section{1. Transkrip Cerita Joko Poleng}

Dari cerita yang dituturkan oleh Mbah Tumper, Yudiono KS menuangkannya dalam buku yang ditulis oleh panitia penyusun sejarah Brebes yang berjudul Legenda \& Kumpulan Ceritera Rakyat Kabupaten Brebes sehingga diperoleh suntingan teks akhir cerita Joko Poleng, sebagai berikut.

Jaka Poleng adalah makhluk yang sudah berbadan halus (bersifat roh). Dia adalah seorang abdi dalem Pendopo Kabupaten Brebes yang masih muda dan masih jejaka yang merupakan utusan dari kerajaan Mataram untuk mencari daerah kekuasaan baru. Saat mencari rumput untuk memberi makan kuda ia melihat selongsong kulit ular belang. Kulit ular pun dimasukkan dalam sakunya. Saat ia kembali ke rumah, tidak ada yang bisa melihat wujud Jaka. Bibi pun lari ketakutan menuju ke dalam rumah dan menemui Kanjeng Bupati dan menceritakan kejadian ajaib tersebut. Kanjeng Bupati pun memerintahkan Jaka untuk menghadapnya. Jaka memenuhi permintaan Kanjeng Bupati... duduk bersilah di hadapan Kanjeng Bupati. Namun, Kanjeng bupati pun hanya bisa mendengar suara Jaka tanpa bisa melihat wujudnya. Kanjeng Bupati memerintahkan untuk menceritakan kejadian aneh saat Jaka mencari rumput. Kemudian Jaka menceritakan perihal selongsong kulit ular yang ditaruh dalam sakunya. Kanjeng pun meminta selongsong ular tersebut dikeluarkan dari sakunya. Tubuh plekathik langsung terlihat bersila di hadapan Kanjeng Bupati. Timbul niat Kanjeng Bupati untuk memiliki selongsong kulit ular tersebut namun ditolak karena Jaka beranggapan karena dia yang menemukan maka dialah yang menjadi pemilik sah selongsong kulit ular tersebut. 
Selongsong kulit ular tersebut merupakan simbol kekuatan yang dimiliki oleh Jaka Poleng yang disebut sebagai ilmu halimun (menghilang). Saat membantu Pangeran Purbaya dan Kanjeng Bupati dalam menghadapi pemerintah Belanda, Jaka Poleng tanpa sengaja menelan selongsong ular tersebut. Tiba-tiba hilanglah wujud dari Jaka hanya suaranya saja yang masih terdengar. Kanjeng Bupati sangat menyesali hal tersebut karena membantu dialah Jaka Poleng tanpa sengaja menelan kulit ular poleng tersebut dan tubuhnya perlahan menghilang. Karena kesaktian Jaka Poleng dan sifat pengabdian Jaka Poleng terhadap Brebes, Kanjeng Bupati menyiapkan satu kamar khusus di belakang kamarnya untuk dijadikan Jaka Poleng sebagai tempat persinggahan. Jaka Polengpun dititipi amanat untuk bisa menjaga masyarakat Brebes. sampai sekarang pun kamar yang diyakini sebagai kamar Jaka Poleng masih ada. Simbol kekuatan Jaka Poleng dan Brebes adalah ular yang kemudian lekat dengan wujud Jaka Poleng sekarang.(poleng: Jw).

Suntingan cerita di atas berdasarkan tuturan langsung dari juru kunci, masyarakat sekitar Pendopo Kabupaten Brebes, dan orang-orang yang terlibat secara langsung dengan tokoh Jaka Poleng yang dibandingkan dengan teks-teks tertulis yang telah beredar di masyarakat.

\section{2. Perbandingan Cerita Jaka Poleng}

Menurut versi-versi cerita yang telah disunting di atas terdapat beberapa perbedaan baik dari segi cerita maupun tokoh-tokohnya, sebagai berikut.

Tabel 1: Versi Lisan

\begin{tabular}{|c|c|c|c|c|}
\hline No & & $\begin{array}{l}\text { Versi A } \\
\text { Kulit Ular }\end{array}$ & $\begin{array}{l}\text { Versi B } \\
\text { Ilmu Halimun }\end{array}$ & $\begin{array}{l}\text { Versi C } \\
\text { Telur Ular Poleng }\end{array}$ \\
\hline 1 & $\begin{array}{l}\text { Nama } \\
\text { Penguasa }\end{array}$ & $\begin{array}{l}\text { K.A. Arya Singa- } \\
\text { sari Pranatayuda I }\end{array}$ & Raja Mataram & $\begin{array}{l}\text { K.A. Arya Singa- } \\
\text { sari Pranatayuda I }\end{array}$ \\
\hline 2 & $\begin{array}{l}\text { Asal } \\
\text { Penguasa }\end{array}$ & $\begin{array}{l}\text { Patih Karawang } \\
\text { Jawa Barat }\end{array}$ & Raja Mataram & $\begin{array}{l}\text { Patih Karawang } \\
\text { Jawa Barat }\end{array}$ \\
\hline 3 & Asal Jaka & $\begin{array}{l}\text { Karawang Jawa } \\
\text { Barat }\end{array}$ & Kerajaan Mataram & $\begin{array}{l}\text { Karawang Jawa } \\
\text { Barat }\end{array}$ \\
\hline 4 & $\begin{array}{l}\text { Nama Awal } \\
\text { Jaka }\end{array}$ & Jaka & Jaka & Jaka \\
\hline 5 & $\begin{array}{l}\text { Penyebab } \\
\text { perubahan } \\
\text { Jaka }\end{array}$ & $\begin{array}{l}\text { Menelan sisa kulit } \\
\text { ular Poleng } \\
\text { (belang) }\end{array}$ & $\begin{array}{l}\text { Menggunakan ilmu } \\
\text { halimun yang belum } \\
\text { sempurna dikuasai }\end{array}$ & $\begin{array}{l}\text { Memakan telur } \\
\text { ular Poleng } \\
\text { (belang) }\end{array}$ \\
\hline 6 & $\begin{array}{l}\text { Nama Akhir } \\
\text { Jaka }\end{array}$ & $\begin{array}{l}\text { Jaka Poleng, Kyai } \\
\text { Poleng, Mbah Jaka }\end{array}$ & Mbah Jaka & $\begin{array}{l}\text { Jaka Poleng atau } \\
\text { Mbah Jaka }\end{array}$ \\
\hline 7 & $\begin{array}{l}\text { Pekerjaan } \\
\text { Jaka }\end{array}$ & Plekathik kuda & Utusan Raja Mataram & Plekathik kuda \\
\hline 8 & Bahasa & Jawa dialek Brebes & Jawa & Jawa \\
\hline 9 & Pengarang & Anonim & Anonim & Anonim \\
\hline
\end{tabular}


Tabel 2: Versi Tulis

\begin{tabular}{|c|c|c|c|}
\hline No & & $\begin{array}{c}\text { Versi Tulis } \\
\text { Legenda dan } \\
\text { Kumpulan Cerita } \\
\text { Rakyat Kabupaten } \\
\text { Brebes } \\
\end{array}$ & $\begin{array}{l}\text { Buku Jaka Poleng } \\
\text { Kabupaten Brebes }\end{array}$ \\
\hline 1 & Nama Penguasa & - & Raja Kameswara \\
\hline 2 & Asal Penguasa & - & Daha Jawa Timur \\
\hline 3 & Gelar Raja & - & Prabu Silih Wangi \\
\hline 4 & Permaisuri & - & Dewi Ningrum \\
\hline 5 & Selir & - & Dewi Pangreyep \\
\hline 6 & Patih & - & Pakebonan \\
\hline 7 & Bahasa & - & Indonesia \\
\hline 8 & Kerajaan & - & Bumi Pakuwon \\
\hline 9 & Pendeta Peramal & - & $\begin{array}{l}\text { Resi Sidi Wacana/ Ki Ajar } \\
\text { Gunung Padang }\end{array}$ \\
\hline 10 & Pengarang & Anonim & Anonim \\
\hline 11 & Penerbit & Kab. Brebes & Kab. Brebes \\
\hline 12 & Tahun Terbit & - & - \\
\hline 13 & Ular Besar & - & Jaka Poleng \\
\hline 14 & Gelar Patih (Jadi Raja) & - & Silih Wangi II \\
\hline 15 & Abdi Setia & - & Ki Lengser \\
\hline 16 & Putra Dewi Ningrum & - & Ciung Wanara \\
\hline 17 & Putra Dewi Pengrenyep & - & Arya Banga \\
\hline 18 & Sungai Pembatas & - & Pemali/ Baribis \\
\hline 19 & Sungai pembuangan & - & Pemali \\
\hline 20 & Penolong Bayi & - & Aki Balangantran \\
\hline 21 & Penguasa Timur & - & Arya Banga \\
\hline 22 & Penguasa Barat & - & Ciung Wanara \\
\hline 23 & Pembagian Kerajaan & - & $\begin{array}{l}\text { Bumi Pakuwon Barat dan } \\
\text { Bumi Pakuwon Timur }\end{array}$ \\
\hline 24 & Jumlah halaman & 74 halaman & 7 halaman \\
\hline
\end{tabular}

Tokoh-tokoh yang ada dalam cerita Jaka Poleng antara versi lisan dan tertulis terdapat beberapa perbedaan atau ketidaksamaan. Tokoh-tokoh yang berkembang pada versi lisan adalah Bupati Brebes saat masa jabatan K.A. Arya Singasari Pranatayuda I, Jaka yang selanjutnya bergelar Jaka Poleng. Pada versi tulis buku Jaka Poleng Cerita-cerita Rakyat Kabupaten Brebes yang dikeluarkan oleh Kantor Kabupaten Brebes, tokoh-tokoh ceritanya adalah Raja Kameswara (Silihwangi I), dengan permaisuri bernama Dewi Ningrum, dan selir bernama 
Dewi Pangrenyep; adik lelaki beliau yang bernama Patih Pakebonan (Silih Wangi II), Ciung Wanara yang merupakan putera dari Permaisuri Dewi Ningrum, Arya Bangga atau Jaka Suruh yang merupakan putera dari Selir Dewi Pangreyep, kemudian tokoh-tokoh Resi Sidi Wacana atau Ki Ajar Gunung Padang (Jaka Poleng), Ki Lengser, Akin dan Nini Balangantran.

Adanya kemunculan nama Prabu Silih Wangi dalam cerita yang ada di Brebes, karena pada dasarnya dulu antara Brebes dan Jawa Barat sudah menjadi satu kesatuan utuh dalam wilayah. Hal ini menyebabkan keberagaman bahasa di beberapa wilayah Brebes masih menggunakan bahasa Sunda sebagai bahasa percakapan sehari-hari. Untuk wilayah Brebes bagian barat bahasa Sunda menjadi bahasa percakapan sehari-hari, sedangkan untuk Brebes tengah sampai timur menggunakan bahasa Brebes (ngapak).

\section{Analisis Struktur Tindakan atau Peristiwa}

Dalam menganalisis struktur Legenda Jaka Poleng, langkah pertama adalah membaca keseluruhan cerita untuk mendapatkan informasi tentang tokoh, tindakan tokoh, serta berbagai peristiwa yang mereka alami. Cerita dibagi dalam beberapa episode untuk mengetahui jalinan peristiwa yang dianalisis.

Setiap episode berisi deskripsi tentang tindakan atau peristiwa yang dialami oleh tokoh-tokoh cerita. Sebagaimana dikatakan oleh Levis-Strauss (Ahimsa-Putra, 2001: 212), tindakan atau peristiwa ini - merupakan mytheme atau cerita ceritheme - hanya ditemukan pada tingkat kalimat. Dalam cerita Jaka Poleng analisis diarahkan pada tindakan atau peristiwa yang dialami oleh tokohtokoh cerita.

(1) “........Jaka Poleng adalah seorang abdi dalam Pendopo Kabupaten Brebes yang masih muda dan masih jejaka yang merupakan utusan dari kerajaan Mataram untuk mencari daerah kekuasaan baru..."

(2) "Saat mencari rumput untuk memberi makan kuda ia melihat selongsong kulit ular belang. Kulit ular pun dimasukkan dalam sakunya."

(3) "Saat ia kembali ke rumah, ia tidak ada yang bisa melihat wujud Jaka. Hanya suaranya saja yang bisa didengar. Bibi pun lari ketakutan menuju ke dalam rumah dan menemui Kanjeng Bupati dan menceritakan kejadian ajaib tersebut. Kanjeng Bupatipun memerintahkan Jaka untuk menghadapnya. Jaka memenuhi permintaan Kanjeng Bupati ia duduk bersilah di hadapan Kanjeng Bupati. Namun, Kanjeng bupati pun hanya bisa mendengar suara Jaka tanpa bisa melihat 
wujudnya. Kanjeng Bupati memerintahkan untuk menceritakan kejadian aneh saat Jaka mencari rumput. Kemuadian Jaka menceritakan perihal selongsong kulit ular yang di taruh dalam sakunya. Kanjeng pun meminta selongsong ular tersebut dikeluarkan dari sakunya. Tubuh plekathik langsung terlihat bersila di hadapan Kanjeng Bupati."

(4) "Timbul niat Kanjeng Bupati untuk memiliki selongsong kulit ular tersebut namun ditolak karena Jaka beranggapan karena dia yang menemukan maka dialah yang menjadi pemilik sah selongsong kulit ular tersebut. Selongsong kulit ular tersebut merupakan simbol kekuatan yang dimiliki oleh Jaka Poleng yang disebut sebagai ilmu halimun (menghilang).

(5) "Saat membantu Pangeran Purbaya dan Kanjeng Bupati dalam menghadapi pemerintah Belanda, Jaka Poleng tanpa sengaja menelan selongsong ular tersebut. Tiba- tiba hilanglah wujud dari Jaka hanya suaranya saja yang masih terdengar. Kanjeng Bupati sangat menyesali hal tersebut karena saat membatu dialah, Jaka Poleng tanpa sengaja menelan kulit ular poleng tersebut dan tubuhnya perlahan menghilang."

(6) "Karena kesaktian Jaka Poleng dan sifat pengabdian Jaka Poleng terhadap Brebes, Kanjeng Bupati menyiapkan satu kamar khusus di belakang kamarnya untuk dijadikan Jaka Poleng sebagai tempat persinggahan. Jaka Poleng pun dititipi amanat untuk bisa menjaga masyarakat Brebes. Sampai sekarang pun kamar yang diyakini sebagai kamar Jaka Poleng masih ada. Sebagai simbol kekuatan Jaka Poleng dan Brebes adalah ular yang kemudian lekat dengan wujud Jaka Poleng sekarang."

Dari enam penggalan cerita ini dapat kita lihat bahwa terdapat relasi oposisi antara tokoh Jaka dengan Kanjeng Bupati, yang dapat dikatakan sebagai hubungan anatara seorang penguasa dengan abdi dalemnya yang terjalin secara baik.

Episode yang mengawali cerita Jaka Poleng adalah saat penugasan mencari daerah kekuasaan baru dalam rangka memperluas daerah kekuasaan. Pada episode ini terjadi pertemuan dua tokoh penting yakni (1) Jaka, sebagai pengembara yang bertugas mencari daerah kekuasaan, (2) Kanjeng Bupati yang memberi pekerjaan Jaka menjadi abdi dalem Pendopo Kabupaten Brebes. Hubungan antara keduanya terbangun secara vertical, bukan horizontal; artinya, pihak bupati yang memberikan Jaka pekerjaan, kedudukannya lebih tinggi - tokoh bupati sebagai tokoh yang lebih tinggi, dan Jaka adalah tokoh di bawahnya.

Tokoh pertama sebagai pengembara yang mencari daerah kekuasaan dalam cerita Jaka Poleng (JP) adalah yang berposisi sebagai tokoh bawahan yang akhirnya memiliki kekuatan yang tinggi dibandingkan tokoh superior. Tokoh 
kedua, yaitu Kanjeng Bupati (KB), yang kemudian menjadikan cerita dimulai, tokoh ini yang mempersilahkan tokoh pertama untuk mendiami daerah Brebes sebagai abdi dalem Pendopo Kabupaten Brebes.

Dari perjalanan dan kisah episode 1 dapat dikemukakan cerithemeceritheme pada Tabel 3 sebagai berikut.

Tabel 3: Ceritheme dan Nama Tokoh

\begin{tabular}{|r|l|l|l|}
\hline \multirow{2}{*}{ No } & \multicolumn{1}{|c|}{ Ceritheme } & \multicolumn{2}{c|}{ Nama Tokoh } \\
\cline { 3 - 4 } & & \multicolumn{1}{c|}{ JP } & \multicolumn{1}{c|}{ KB } \\
\hline 1 & Strata Sosial Jawa & Golongan bawah & Golongan atas \\
\hline 2 & Hubungan Sosial & Diperintah & Memerintah \\
\hline 3 & Tugas social & Tang diberi tugas & Pemberi tugas \\
\hline 4 & Kekuasaan & $\begin{array}{l}\text { Memutuskan dan } \\
\text { mutlak }\end{array}$ \\
\hline 5 & Tempat tinggal & $\begin{array}{l}\text { Pendopo } \\
\text { Kabupaten Brebes }\end{array}$ & $\begin{array}{l}\text { Pendopo } \\
\text { Kabupaten Brebes }\end{array}$ \\
\hline
\end{tabular}

Dari rangkaian ceritheme pada Tabel 3 dapat dilihat adanya transformasi atau perbedaan unsur. Dalam ceritheme strata sosial, JP dan KB menunjukkan kedudukan berbeda yang memunculkan struktur hubungan bahwa KB yang memiliki kekuasaan untuk memerintah JP.

\section{1. Penemuan Selongsong Kulit Ular}

Episode kedua adalah episode JP dalam melaksanakan tugasnya sebagai abdi dalem Pendopo Kabupaten Brebes. Ceritheme "tempat menemukan selongsong ular sakti" berada di sekitar daerah Brebes. Pada episode kedua ini tokoh JP menemukan kunci utama dari cerita Jaka Poleng. Selongsong kulit ular ini menjadi tumpuan munculnya kisah yang lebih kompleks.

\section{2. Perubahan Tokoh}

Episode perubahan adalah episode ketika tubuh JP berubah tidak terlihat (kasat mata) saat mengantongi selongsong kulir ular Poleng yang ternyata memiliki kekuatan sakti. Kekuatan inilah yang memicu perubahan besar pada hubungan antara JP dan KB. Episode perubahan ini menampilkan kekuatan selongsong kulit ular Poleng yang melekat pada diri JP. 


\section{3. Penitisan Tokoh}

Episode nitis adalah episode keempat dan kelima pada cerita ini. Kata nitis berarti menjelma (merasuk) atau inkarnasi dari satu tokoh ke tokoh lain. Penitisan (penjelmaan) ini hanya dapat dilakukan oleh orang sakti atau memiliki kekuatan lebih. Dalam cerita Jaka Poleng, tokoh yang nitis adalah JP yang semula berwujud manusia biasa berubah menjadi ular Poleng (belang-belang) saat meminum air yang telah dicampur dengan selongsong kulit ular yang dibakar. Jaka Poleng kemudian berubah wujud dan menghilang tanpa bisa kembali lagi ke keadaan semula sebagai manusia. Kejadian ini dipicu oleh perebutan simbol kekuatan yaitu selongsong ular. Perebutan ini dilakukan oleh JP dan KB.

Atas dasar ceritheme di atas, tokoh yang selalu terkait denga episode nitis adalah JP dan KB. Ceritheme di atas digambarkan seperti terlihat pada Tabel 4 sebagai berikut.

Tabel 4: Perebutan Selongsong Kulit Ular

\begin{tabular}{|l|l|l|}
\hline \multicolumn{1}{|c|}{ Ceritheme } & \multicolumn{1}{|c|}{ KB } & \multicolumn{1}{c|}{ JP } \\
\hline Alasan nitis & $\begin{array}{l}\text { Ingin memiliki kekuatan yang } \\
\text { sama seperti JP yaitu menghilang }\end{array}$ & $\begin{array}{l}\text { Tetap mempertahankan } \\
\text { kekuatan yang dimilikinya }\end{array}$ \\
\hline Lokasi nitis & - & Pendopo Kabupaten Brebes \\
\hline Sasaran nitis & - & JP \\
\hline $\begin{array}{l}\text { Jenis makhluk } \\
\text { yang digunakan } \\
\text { nitis }\end{array}$ & - & $\begin{array}{l}\text { Hewan ular yang memiliki } \\
\text { motif belang (poleng) }\end{array}$ \\
\hline $\begin{array}{l}\text { Kedudukan } \\
\text { makhluk }\end{array}$ & Penguasa Brebes & $\begin{array}{l}\text { Abdi dalem Pendopo } \\
\text { Kabupaten Brebes }\end{array}$ \\
\hline Proses nitis & - & Langsung \\
\hline Jalan nitis & - & Melalui mulut \\
\hline Keadaan makhluk & & Sadar \\
\hline
\end{tabular}

Episode nitis tersebut merupakan klimaks cerita. Alasan nitis pada ceritheme di atas adalah perebutan simbol kekuatan antara KB dan JP. Sebagai permilik sah simbol kekuatan (selongsong kulit ular), JP berhak mempertahankan. Saat mempertahankan, kulit selongsong ular tersebut ditelan dan menyatu dengan tubuhnya sehingga JP tidak bisa kembali ke wujud semula sebagai manusia biasa. KB memiliki peranan penting pada proses nitis JP. 
Setelah nitis, JP berubah menjadi sesosok ular yang memiliki motif belang. Sesekali JP menampakkan dirinya sebagai wujud manusia biasa saat-saat tertentu. Bukti artefak kematian JP tidak ditemukan sehingga kepastian akan keberadaan JP adalah makhluk yang nitis menjadi ular Poleng yang memiliki kekuatan sakti tidak ada.

\section{4. Penghargaan terhadap JP}

Episode terakhir, episode enam, merupakan akhir penghargaan dan rasa penyesalan tokoh KB atas apa yang telah menimpa tokoh JP. Setelah tubuh Jaka Poleng berubah menjadi ular berbadan belang, tokoh KB menyesal. Permintaan $\mathrm{KB}$ atas simbol kekuatan yaitu selongsong kulit ular, menjadi penyebab Jaka Poleng menelan selongsong kulit ular tersebut.

Dalam episode terakhir ini sebagai rasa penyesalan dan terimakasih $\mathrm{KB}$ kepada JP, JP diberi sebuah permintaan yang pasti dikabulkan. Permintaan tersebut berupa kamar kosong yang digunakan JP untung singgah. Permintaan tersebut disanggupi oleh KB. Posisi kamar berada persis di belakang kamar KB, hal ini berkaitan dengan penghargaan kepada JP semasa ia mengabdi pada KB.

\section{Tanggapan Masyarakat}

Tanggapan masyarakat pada cerita Jaka Poleng erat kaitannya dengan konsep mitos yang menyertai cerita Jaka Poleng. Dalam mitos yang melahirkan beberapa tradisi terdapat perilaku dan konsep terhadap cerita Jaka Poleng. Setiap mitos yang berkembang di masyarakat mengandung nilai-nilai kesakralan, yaitu memanifestasikan diri sebagai sebuah realitas yang secara keseluruhan berbeda tingkatannya dari realitas-realitas "alami” (Eliade, 2002: 2).

Mitos-mitos yang menyertai kisah Jaka Poleng ditanggapi masyarakat sebagai sesuatu yang sakral maupun kebalikannya menganggap bahwa cerita Jaka Poleng merupakan cerita pengantar tidur. Dalam tradisi yang menyangkut cerita Jaka Poleng ada hal-hal yang masih tetap dipertahankan, namun ada pula yang sudah mulai dihilangkan atau dikurangi intensitasnya. Hal itu disebut profane (Eliade, 2002:7), yang berarti ruang dan waktu bersifat homogen, tidak ada ruang istimewa, dan tidak ada waktu istimewa atau bisa dikatakan dengan pengingkaran terhadap adanya sesuatu yang sakral. 
Dalam menerima Legenda Jaka Poleng masyarakat Brebes dapat dikelompokkan menjadi 2 (dua) kategori, yang pertama adalah masyarakat yang meyakini bahwa Jaka Poleng masih tetap hidup sampai sekarang, yang kedua adalah masyarakat yang meyakini bahwa Jaka Poleng hanya sebuah cerita pengantar tidur yang tidak diyakini keberadaannya; kategori kedua merupakan masyarakat yang tidak mempercayai legenda adanya tokoh Jaka Poleng.

\section{1. Kategori Positif}

Sistem mata pencaharian sebagian masyarakat Brebes yang didominasi oleh nelayan dan petani mempengaruhi sistem kepercayaan yang dianut masyarakat setempat. Masyarakat Brebes sebagian besar masih mempercayai cerita-cerita yang memiliki unsur magis dan meyakini benar keberadaannya. Hal-hal yang berkaitan dengan cerita mistis tersebut akan dipatuhi dan tidak akan dilanggar oleh masyarakat. Begitupun dengan sikap masyarakat yang meyakini keberadaan Jaka Poleng dan percaya Jaka Poleng masih hidup untuk menjaga warga Brebes, terbukti dengan sikap warga Brebes yang bersikap ramah dengan ular, terutama ular belang. Warga meyakini ular belang adalah perwujudan dari Jaka Poleng sehingga tidak boleh diganggu.

\section{2. Kategori Negatif}

Kategori tanggapan masyarakat Brebes yang kedua adalah kategori negatif, yang tidak mendukung keberadaan Jaka Poleng. Seiring dengan perkembangan jaman dan pendidikan, legenda Jaka Poleng tidak lagi mutlak diakui oleh masyarakat Brebes. Sebagian mayarakat mulai menganggap Jaka Poleng hanya sebuah cerita tentang tokoh khayal sebagai pengantar tidur.

Ritual-ritual untuk memperingati Jaka Poleng hanya merupakan sebuah tradisi yang dilakukan turun-temurun. Hal ini berkaitan dengan sistem religi orang Brebes yang tidak lagi Islam abangan yang masih mencampur unsur magis dengan ajaran Islam. Mereka percaya bahwa seseorang yang telah meninggal tidak akan lagi berurusan dengan dunia. Jaka Poleng yang telah meninggal tidak lagi dipercaya hadir di tengah-tengah masyarakat Brebes melainkan tokoh yang hanya ada dalam dunia khayal saja. 


\section{3. Tanggapan Pembaca}

Sebagai tokoh utama dan menjadi judul utama cerita Jaka Poleng, sosok Jaka Poleng merupakan tokoh yang dikeramatkan oleh sebagian masyarakat Brebes. Masyarakat menganggap Jaka Poleng adalah tokoh yang memiliki kekuatan melebihi kekuatan manusia biasa.

Bukti bahwa masyarakat menganggap cerita Jaka Poleng sangat sakral adalah tidak ada yang berani mementaskan cerita Jaka Poleng, baik dalam bentuk wayang, ketoprak, seni tari, drama, film atau pun lainnya. Bentuk penyebaran cerita Jaka Poleng adalah lisan (disebarkan dengan cara diceritakan melalui mulut ke mulut bukan dalam bentuk pertunjukan).

\section{4. Tanggapan terhadap Kamar Jaka Poleng}

Kamar yang diyakini sebagai kamar Jaka Poleng setiap hari Jumat selalu dirapikan, sebagai bentuk penghormatan terhadap keberadaan Jaka Poleng. Ritual ini selalu dilakukan karena ada anggapan jika ritual membersihkan kamar Jaka tidak dilakukan akan terjadi suatu malapetaka. Menurut juru kunci dan masyarakat sekitar pernah terjadi keanehan di lingkungan kamar Joko Poleng yang akhirnya dapat dipahami sebagai bentuk kehadiran Jaka Poleng. Kamar yang tak pernah digunakan untuk tidur selalu tampak berantakan di pagi hari seperti ada seseorang yang baru saja memakai tempat tidur tersebut untuk tidur.

Memasuki kamar Jaka Poleng pun harus mematuhi aturan yang berlaku. Pengunjung harus berlaku sopan dan wajib mengucapkan salam terlebih dahulu kepada Jaka Poleng didampingi oleh juru kunci. Pengunjung dilarang membawa barang-barang elektronik seperti kamera, handphone atau peralatan elektronik yang sifatnya mengganggu ketenangan ruangan. Pengunjung yang akan mengambil gambar pun diperbolehkan setelah juru kunci melakukan ritual khusus dengan membaca mantera yang isinya meminta izin kepada si pemilik kamar (Jaka Poleng). Jika sang juru kunci memberi isyarat bahwa pengambilan gambar boleh dilakukan pengunjung diperbolehkan mengambil gambar, jika juru kunci tak memnghendaki pengambilan gambar, maka pengunjung tidak diperbolehkan mengambil gambar. Jika pengunjung tetap nekat walaupun tidak mendapatkan izin, banyak kemungkinan gambar tidak ada yang tercetak atau rusak. Yang 
menghendaki boleh atau tidak bukanlah juru kunci melainkan pemilik kamar, Jaka Poleng, yang disampaikan melalui juru kunci.

\section{5. Tanggapan terhadap Sesajian}

Selain kamar yang dianggap sakral, ritual pemberian sesaji pada malam Jumat kliwon dan hari biasa merupakan suatu keharusan. Ritual ini mengisyratkan bahwa masyarakat masih percaya sosok Jaka Poleng adalah makhluk dari alam lain yang memiliki kebutuhan sama seperti manusia biasa. Pemberian sesaji ini biasanya dilakukan di tempat-tempat yang dianggap keramat dan mempunyai nilai magis yang tinggi. Prosesi tersebut terjadi sudah sangat lama, bisa dikatakan sudah berasal dari nenek moyang kita yang mempercayai adanya pemikiranpemikiran yang mistis. Kegiatan ini dilakukan oleh masyarakat guna mencapai sesuatu keinginan atau terkabulnya sesuatu yang bersifat duniawi.

\section{6. Tanggapan terhadap Cerita}

Cerita Jaka Poleng sangat populer di kalangan masyarakata Brebes. Salah satu cerita dituturkan oleh Malekha, informan yang melihat sosok yang pernah diceritakan ayahnya saat Malekha kelas 1 SD. Saat itu Malekha sedang berjalan menyusuri lorong di belakang Pendopo untuk membeli bumbu dapur pada waktu magrib (sekitar pukul enam sore.) Di atas pagar pendopo Malekha melihat sosok tinggi besar memakai baju loreng (lurik) menggunakan topi hitam (topi model petani orang jaman dahulu) sedang merokok. Tokoh tersebut mirip seperti yang diceritakan oleh ayah Malekha saat hendak tidur. Malekha meyakini dialah sosok Jaka Poleng. Cerita-cerita yang berkembang di masyarakat membuktikan bahwa masyarakat menganggap bahwa cerita Jaka Poleng memiliki nilai magis dan sakral. Sosok Jaka Poleng disakralkan sebagai cerita yang memiliki nilai magis.

\section{Makna Simbolik Legenda Jaka Poleng}

\section{1. Tradisi Membersihkan Kamar Jaka Poleng}

Tradisi membersihkan kamar Jaka Poleng telah ada sejak Pendopo Kabupaten Brebes ada. Tradisi tersebut telah menjadi agenda rutin dari pendopo. Untuk melaksanakan tradisi tersebut, diperintahlah juru kunci yang bertanggung jawab atas perawatan kamar Jaka Poleng. Ritual membersihkan kamar dilaksanakan setiap malam Jumat Kliwon. Tujuan dari tradisi membersihkan 
kamar Jaka Poleng ini sebagai konsekuensi anggapan bahwa Jaka Poleng adalah tokoh yang melindungi rakyat Brebes, sehingga untuk menghormatinya kamar sebagai tempat persinggahan Jaka Poleng harus selalu dibersihkan.

\section{2. Makna Simbolik Tradisi Membersihkan Kamar}

Simbol merupakan perantara untuk menguraikan atau menggambarkan sesuatu yang sifatnya abstrak. Tradisi membersihkan kamar mengandung makna sebagai berikut.

(1) Mengganti sprei sebagaimana adat kebiasaan dalam kehidupan sehari-hari, ritual penggantian sprei berkaitan dengan keyakinan bahwa sprei tersebut digunakan pada tempat tidur Jaka Poleng dan Jaka Poleng menggunakannya. Karena kegunaan tersebut selayaknya manusia biasa dalam waktu berkala sprei harus diganti agar nyaman untuk digunakan oleh Jaka Poleng.

(2) Menyapu lantai, layaknya kamar yang memiliki penghuni kebersihan kamar harus dijaga.

(3) Menyiapkan pakaian di atas tempat tidur, merupakan ritual yang wajib disediakan. Di dalam almari di kamar Jaka Poleng terdapat beberapa helai pakaian dan setiap ritual membersihkan kamar juga dilakukan ritual mencuci pakaian Jaka Poleng.

(4) Menyiapkan makanan, minuman dan makanan pendamping seperti lauk telor, sate hati ayam, ulam plirik (ikan lerek/ sejenis ikan asin yang panjang), tahu, tempe, kluban (olahan sayuran dengan bumbu kelapa pedas), dan nasi satu piring, adalah satu hal yang tidak boleh dilupakan setelah ritual membersihkan kamar dilakukan.

Malam Jumat dipilih sebagai waktu yang ditentukan untuk membersihkan kamar Jaka Poleng sesuai dengan anggapan bahwa Jumat adalah nama hari yang dianggap paling sakral. Kalau mendengar kata Jumat, yang terbayang di kepala kita adalah keagungan, kesucian. Bagi umat tertentu, Jumat memiliki makna tersendiri. makna kesucian, keagungan dan keimanan.

Dalam tradisi suku Jawa dan Sunda, ada istilah Jumat Kliwon. Hal ini erat kaitannya dengan tradisi yang sudah turun temurun, bagi sebagian masyarakat 
Jawa atau Sunda. Kedua suku itu selama ini memang dikenal sebagai salah satu suku yang sangat kental dengan tradisi Jumat Kliwonnya. (artikelindonesia.com).

\section{3. Makna Simbolik Sesajian atau Makanan Jaka Poleng.}

Sebagai penghormatan terhadap Jaka Poleng perlu adanya pemberian sesaji yang berupa makanan dan minuman yang digemari oleh Jaka Poleng. Dalam Legenda Jaka Poleng ini, sajen mengandung makna sebagai berikut.

Makanan tigan (telor), sate hati ayam, ulam plirik (ikan lerek/ sejenis ikan asin yang panjang), tahu, tempe, kluban (olahan sayturan dengan bumbu kelapa pedas), nasi satu piring. Sajian makanan ini merupakan makanan khas bagi masyarakat Brebes.

(1) Tigan atau telor yang kini merupakan ikon dari kota Brebes mengibaratkan bahwa Jaka Poleng adalah orang asli Brebes yang menyukai telur. Telur juga memiliki makna filosofis yang menandakan cikal bakal kehidupan di dunia, bahwa manusia terbentuk dari rahim seorang wanita; sedangkan bulat telur melambangkan dunia dan kehidupan.

(2) Sebagai jelmaan ular, Jaka Poleng menyukai hati ayam, sebagaimana makanan utama yang disukai ular adalah ayam.

(3) Ulam Plirik menggambarkan kondisi alam brebes yang tidak hanya didominasi kaum petani melainkan kaum nelayan. Ikan plirik mewakili kaum nelayan Brebes.

(4) Kluban atau olahahan sayuran dengan bumbu pedas merupakan wakil dari penduduk Brebes yang merupakan petani dan salah satuya petani sayuran.

Dari komposisi makana utama yang disajikan dalam ritual membersihkan kamar Jaka Poleng terlihat keseimbangan komposisi yang mewakili masyarakat Brebes dan sesuai dengan kondisi masyarakat Brebes yang bersifat agraris dan sebagian nelayan. Sebagai pelindung masyarakat Brebes Jaka Poleng harus mewakili kedua masyarakat yang dilindunginya yakni masyarakat nelayan dan masyarakat petani. Demikian pula makna yang dapat dipetik dari makanan tambahan, sebagai berikut. 
(1) Makanan tambahan ubi kayu (singkong) bakar merupakan simbol kemakmuran: sifat ubi kayu bisa ditanam dalam kondisi tanah apapun, yang menggambarkan kondisi tanah Brebes selain cocok sebagai pertanian sayur juga cocok bagi tanaman-tanaman lahan kering.

(2) Kembang telon yang terdiri dari melati, mawar, cempaka, berasal dari kata telu (tiga), dengan harapan agar meraih tiga kesempurnaan dan kemuliaan hidup (tri tunggal jaya sampurna), yakni sugih (kaya akan) banda (harta), sugih ilmu, sugih kuasa, atau jabatan.

(3) Rokok kretek, yang dibuat khusus tanpa filter, kadang pun diracik sendiri. Sesajian rokok dipercaya merupakan kesukaan Jaka Poleng yang menandakan kejantanan kaum adam selain sebagai pemimpin rumah tangga. Rokok yang pertama kali digunakan adalah rokok siong, kemudian tidak lagi diproduksi, dan digantikan dengan rokok layar, yang merupakan rokok-rokok khas masyarakat Jawa.

\section{Nilai-nilai Cerita Jaka Poleng}

Keberadaan cerita Jaka Poleng memiliki nilai-nilai yang masih terus dilestarikan oleh masyarakat Brebes. Nilai-nilai yang timbul dari cerita Jaka Poleng meliputi sebagai berikut.

\section{1. Nilai Pelestarian Alam}

Cerita Jaka Poleng merupakan usaha kreatif yang menciptakan ajaran bahwa manusia harus menghormati alam dengan menjaga kelestariannya. Dengan adanya aroma mitis dalam cerita Jaka Poleng berkembang kepercayaan di masayarakat Brebes untuk tidak membunuh ular secara sembarangan. Jika ular tersebut muncul dan tidak mengganggu maka menjadi pantangan untuk membunuhnya. Selain itu masyarakat percaya bahwa salah satu ular yang mereka jumpai adalah ular Jaka Poleng, sehingga mereka tidak berani membunuh ular.

\section{2. Nilai Pedagogis}

Cerita Jaka Poleng memiliki nilai-nilai pendidikan positif. Selain mengajarkan pada masyarakat tentang hidup yang seimbang, tokoh Jaka Poleng merupakan tokoh panutan masyarakat Brebes, sebagai abdi dalem pendopo yang memiliki sifat berani, setia, dan jujur. Ia bersifat pemberani dengan menggunakan 
kesaktian selongsong ular yang dimilikinya untuk membantu Pangeran Purbaya dalam melawan Belanda.

\section{3. Nilai Kearifan Lokal}

Cerita Jaka Poleng memberi manfaat atau sumber kearifan local, yang terlihat pada mitos sungai Pemali yang memiliki peranan penting dalam menghalau ilmu hitam. Setiap ilmu hitam yang melewati sungai Pemali akan luntur kekuatannya. Sedangkan kamar yang diyakini sebagai kamar Jaka Poleng dimaksudkan sebagai kamar kontemplasi, sedhakep siniku tunggal (sholat tahajud). Tafsir ini dimaksudkan idealnya pemimpin Brebes di setiap jajaran birokrasi memiliki kualifikasi sebagai figur yang cerdas, baik secara intelektual, spiritual, maupun emosional.

\section{4. Nilai Pelestarian Budaya}

Cerita Jaka Poleng telah tersebar di masyarakat Brebes secara luas dengan sifat-sifat mereka yang dapat dijadikan suri tauladan. Cerita Jaka Poleng memberikan pengenalan pola kebudayaan, pemerintahan, dan kehidupan pada masa itu, jaman dahulu. Fungsi pelestarian budaya ini memberikan jaminan bahwa berbagai seni tradisi, adat istiadat, serta ritual yang ada tetap dilaksanakan dan dilestarikan.

\section{5. Nilai Sosial Keagamaan dan Ekonomi}

Nilai sosial keagamaan yang ada dalam cerita Jaka Poleng adalah manusia harus mempunyai sifat-sifat luhur, berbakti kepada orang tua (sesepuh) dan tetap menjalin silaturahmi. Nilai-nilai yang dapat diteladani adalah sifat tidak pendendam, yang ditunjukkan oleh Kanjeng Bupati kepada abdinya yaitu Jaka Poleng, walaupun abdinya telah menolak perintahnya untuk memberikan selongsong kulit ular.

Terdapat tradisi memperingati Jaka Poleng. bukan untuk memperingati kematiannya, karena Jaka Poleng dipercaya makareman atau menjadi bangsa lelembut dan sampai saat ini masih hidup (belum mati), maka setiap tanggal 18 Januari diadakan upacara dalam rangka mengingat beliau serta untuk meminta berkah dari sesepuh Brebes tersebut. Acara peringatan tersebut sekaligus menjadi hari peringatan hari jadi Kabupaten Brebes. 
Tradisi peringatan biasanya dilangsungkan secara meriah oleh berbagai kalangan warga masyarakat Brebes, dimulai dengan kirab oleh Bupati Brebes beserta Muspida dari Desa Kaligangsa Wetan menuju Pendopo Kabupaten Brebes.

\section{6. Nilai Legitimasi Kepemimpinan Penguasa Setempat}

Legitimasi dalam ilmu politik diartikan sejauh masyarakat mau menerima dan mengakui wewenang, keputusan atau kebijakan yang diambil oleh pemimpin. Cerita Jaka Poleng berfungsi sebagai legitimasi kekuasaan pada efektivitas kepemimpinan politik yang ditentukan oleh legitimasi yang kuat dari masyarakat. Dalam budaya kejawen, legitimasi mistis yang telah menjadi mitos rakyat mempengaruhi proses politik yang berlangsung di dalamnya. Kepemimpinan seorang tokoh tidak terlalu kuat tanpa adanya dukungan mistis dari penguasa yang memiliki wilayah tersebut, yaitu Jaka Poleng. Dalam legitimasi kekuasaan pemimpin di Brebes (Bupati) menggunakan sumber kekuatan dari Jaka Poleng, dengan demikian melanggengkan kekuasaan pemimpin di Brebes di mata rakyatnya. Dengan demikian Cerita Jaka Poleng memberikan fungsi dalam hal penjagaan wibawa pemimpin Brebes sehingga tetap terjaga proses pemerintahan yang harmonis.

\section{Simpulan}

Dalam perbandingan, versi-versi cerita Jaka Poleng memiliki persamaan pada tokoh cerita yaitu Jaka Poleng; perbedaan cerita terletak pada proses perubahan Jaka Poleng menjadi ular belang. Tanggapan masyarakat Brebes berupa masih berlakunya mitos-mitos yang dipercaya memiliki hubungan erat dengan ketokohan Jaka Poleng. Tradisi yang berkaitan dengan Jaka Poleng pun masih dilaksanakan sampai sekarang oleh masyarakat Brebes dan mengandung makna dan nilai-nilai yang perlu dilestarikan.

\section{Daftar Pustaka}

Abdullah, Imran T. 1994. "Resepsi Sastra Teori dan Penerapannya," dalam Jabrohim (Editor), Teori Penelitian Sastra. Yogyakarta: IKIP Muhammmadiyah Yogyakarta. 
Ahimsa-Putra, Heddy Shri. 2001. Strukturalisme Levi- Strauss: Mitos dan Karya Sastra. Yogyakarta: Penerbit Galan Press.

Atmazaki. 1990. Ilmu Sastra, Teori, dan Terapan. Padang: Angkasa Raya.

BAPPEDA. 2004. Brebes Tempo Dulu dan Benda-benda Cagar Budaya Kabupaten Brebes. Brebes: BAPPEDA.

Chamamah, Siti. 1991. Hikayat Iskandar Zulkarnaen: Analisis Resepsi. Jakarta: Balai Pustaka.

Dananjaja, James. 2002. Folklor Indonesia: Ilmu Gosip, Dongeng, dan Lain-lain. Cetakan ke-6. Jakarta: Pustaka Utama Grafiti.

Eliade, Mircea. 2002. Sakral dan Profan. Yogayakarta: Fajar Pustaka Baru.

Geerttz, Clifford. 1989. Abangan, Santri, Priyayi dalam Masyarakat Jawa. Jakarta: Pustaka Jaya.

Gunawan. 2009. Sejarah Mentalitas Brebes. Brebes: BAPPEDA.

Iser, Wolfgang. 1978. The Act of Reading: A Theory of Aesthetic Response. Maryland: The John Hopkins Press.

Jauss, Hans Robert. 1983. Toward an Aesthetic of Reception. United States of America: University of Minnesota Press.

Junus, Umar. 1985. Resepsi Sastra: Sebuah Pengantar. Jakarta: PT Gramedia.

Kleden, Ninuk. 2008. "Pengalihan Wacana: Lisan dan Teks," dalam Pudentia (Editor), Metodologi Kajian Sastra Lisan. Jakarta: Asosiasi Tradisi Lisan.

Miles, Matthew B. \& A. Michael Huberman. 1992. Analisis Data Kualitatif. Terjemahan Tjetjep Rohendi Rohidi. Jakarta: Universitas Indonesia Press.

Supardi. 1998. Legenda dan Kumpulan Ceritera Rakyat Kabupaten Brebes. Brebes: Pemerintah Kabupaten Brebes.

Thohir, Mudjahirin. 2007. Memahami Kebudayaan: Teori, Metodologi, dan Aplikasi. Semarang: Fasindo Press.

Tim Penyusun Sejarah Brebes. 1988. Sejarah dan Hari Jadi Kabupaten Brebes. Brebes: Pemerintah Kabupaten Brebes. 
Yudiono KS. 2005. Cerita Rakyat dari Brebes Babad Bumi Pakuwon. Jakarta: PT Grasindo

Moleong, Lexy J. 2002. Metodologi Penelitian Kualitatif: Bandung: Rosdakarya. 